\title{
A Pathological Study on Legal Status of Supreme Councils in the Islamic Republic of Iran
}

\author{
Mohsen IRAJ \\ PhD Student, Public Law, Islamic Azad University, Science and Research Branch, Tehran, Iran; \\ Email: irajimohsen@yahoo.com
}

\begin{abstract}
The multiplicity of institutions prescribing behavioral rules is one of the law-based orders in Iran. Although the Iranian Constitution is legislated at Islamic Consultative Assembly (Majlis) and the validity of its decisions are bound to approval from the Council of Guardians, the same law has established those institutions assigning that authority. One instance of such institutions is the Supreme National Security Council whose decisions are applicable after approval from by the Supreme Leader. The Supreme Administrative Council and the Supreme Council of the Cultural Revolution are other instance of such institutions. Undoubtedly, this multiplicity threatens the establishment of order under law. Therefore, it is necessary to outline the status of approvals by each of those bodies in the hierarchy of legal sources in order to mitigate the scope of threat. This paper intended to describe the supreme councils from that very perspective, making an effort to assess the relationships between those institutions and the governing branches in the country and examining their status in the Iranian administrative system.
\end{abstract}

Keywords: Supreme Administrative Council, Supreme Council of Cultural Revolution, Supreme National Security Council, Iranian Constitution

\section{Introduction}

In Iran, there are there are nearly fifty supreme councils, each established according to its own specific tasks and functions. Here is the major question: Are these councils all necessary in the system? And if the sequence of these councils is necessary, what qualification should supreme councils meet to continue operating?

Currently, there are numerous supreme councils in the country, each vested with various tasks, including legislation, adoption of regulations, policy-making, strategic leadership, advisory, etc. Nonetheless, the councils vary in their scopes of responsibilities, so that some have been assigned to one or several tasks, while others deal with all the mentioned tasks (Ghazi Seyed Abolfazl, 1991, vol. 1, p. 247) 
There is also disagreement about the tasks of each council. Some authorities believe that a certain council is vested with legislation, while other expands its tasks to approval of laws and policy-making (Hashemi, SM, 2005 and 2014).

Another point is that many of these supreme councils operate through organizing headquarters and secretary offices, which carry out tasks incurring a great deal of material and non-material costs for the administrative system. Therefore, it is highly reasonable and meticulous to explore the phenomenon of supreme councils in the country and question whether or not their existence is necessity.

\section{Legal status and significance of supreme councils}

\subsubsection{Supreme Councils}

\subsubsection{Definition and number of supreme councils}

Unfortunately, there is no statistics available about the exact number of neither current and former supreme councils nor the active and inactive councils in Iran. According to several reports, however, there have so far been nearly a total of 50 supreme councils titled council, headquarters, etc. in the country, according to the Management and Planning Organization (November 2003), Bill on Integration of Supreme Councils by the Supreme Administrative Council (July 2007) and news articles about supreme councils in the Iranian administrative system. These supreme councils include: 1. Supreme Council of Cultural Revolution, 2. Supreme Council of Youth, 3. Supreme Council of Information, 4. Applied Scientific Research Council, 5. Council of Physical Education Organization, 6. Literacy Support Supreme Council, 7. Vocational Training Coordination Headquarters, 8. Non-oil Export Development Council, 9. Employment Supreme Council, 10. Economic Council, 11. Supreme Council of Africa, 12. State Economic Coordination Headquarters, 13. Market Regulation Support Program Headquarters , 14. Currency Market Regulation Committee , 15. Administrative Supreme Council, 16. Standards Supreme Council, 17. National Security Supreme Council, 18. Free Trade and Industrial Zones Supreme Council, 19. International Legal Services Supervision Supreme Council, 20. War on Drugs Headquarters, 21. Atomic Energy Council, 22. Environmental Protection Supreme Council, 23. Water Resources Supreme Council, 24. Nomads Supreme Council, 25. Science, Research and Technology Supreme Council, 26. Biotechnology Supreme Council, 27. Iran and World Tourism Supreme Council, 28. Information Technology Supreme Council, 29. Informatics Supreme Council 30. Supreme Council of IES (Information Exchange Security), 31. Cyberspace Supreme Council, 32. Space Supreme Council, 33. Education Supreme Council, 34. Employment Supreme Council, 35. Non-oil Export Development Council, 36. Exports Supreme Council, 37. Supreme Council of Technical and Engineering Services Exports Coordination, 38. Foreign Exchange Reserves Board of Trustees, 39. Supreme Council of Welfare and Social Security, 40. Money and Credit Council, 41. Insurance Supreme Council, 22. Supreme Council of Consumption Patterns, 23. Supreme Council of Cultural Heritage and Tourism, 24. Judicial Supreme Council, 45. Registration Supreme Council, 46. Technical 
Supreme Council, 47. Supreme Council of Energy (newly established), 48. Supreme Council for Promotion of Virtue and the Prevention of Vices, and possibly many other titles!

A quick overview will reveal that many supreme types of council in Iran have formed in face of legal and administrative loopholes in the Iranian macro-scale management system. Therefore, establishment of such councils served to enhance the efficiency of the entire system. However, the supreme council have turned into essential procedures, raising the question whether or not their sequence needs to be involved in the system. Whether or not the existence of multiple supreme councils is consistent with the logic of governance based on religious democracy. And assuming the sequence of these councils is necessary, what qualification should supreme councils meet to continue operating? (Hashemi, SM, 2005 and 2014).

\subsubsection{Reasons behind unjustified involvement of supreme councils}

The multiplicity of supreme council firstly hinders the meetings or proceedings held based on expert opinions, and secondly, interference between their scopes of activity leads to uncoordinated decision and administrative loopholes even if their tasks lies in a reformulated logic.

When criticizing supreme councils, the focus is only on the multiplicity and overlapping of their activities. Although it is an appropriate point in terms of administration and practice, it is an outcome of the sequence of imposed trends in the past.

\subsubsection{Legislative status and condition of supreme councils}

\subsubsection{Legislative status of supreme councils}

Recognition of the legislative status for supreme councils implies the engagement of executive branch in the legislative arena. Naturally, the involvement of the executive branch in the legislative arena facilitates the formation of corruption in the Iranian executive system, where the executive branch prevails other branches and the general public. As a result, there will be greater tendency toward monopoly and government dictatorship.

In a democracy, people elect directly or indirectly for representatives who are assigned to handle various affairs in the realms of legislation, law enforcement, dealing with offenders, protection of security and so on. According to Article 85 of the Iranian Constitution, legislation have been vested only in Majlis, and not the supreme councils nor the Nation's Exigency Council or other entities.

The principle states: "Majlis cannot delegate its legislative powers to other persons or entities." Therefore, Majlis violates law if it ever delegates such authority to other entities. It should be noted that the logic behind the constitution in this context is non-impairing, since the executive branch does not have the right to interfere in legislation in order to realize true democracy and prevention of tyranny (Morteza'i, SA, 2011).

There is no identical definition to supreme councils either in legal or administrative terms. The outcome of poor definition and precise legal boundaries about the status and tasks of supreme 
councils is that liability of decisions by supreme councils is not held by any specific entities or bodies before the representatives of Iranians at Majlis. In this regard, Majlis is unable as a supervisory entity to question the supreme councils (Katuzian, N., 2003).

Apparently, the tasks of supreme councils should be limited to "determining the overall administrative policies and strategic guidance in certain administrative areas" and "executive decisions and communication to executive agencies", which are deemed extensive tasks per se. Before archiving that status, supreme councils firstly need to outline where they stand according to their scope of powers given by the Constitution and Majlis to government. In fact, the decisions of supreme councils should not be assumed prevailing over Majlis. Secondly, the number of supreme councils should be limited in a way not exceed and interfere in their scopes of authority. Thirdly, the responsibilities of supreme councils should be specified in detail and then be recognized by the political elite, so as to avoid differing impressions on the tasks of supreme councils. Obviously, the responsibilities of supreme councils should be described based on the principles of the Constitution and regulations of Majlis. It is also noteworthy that the "legislative weaknesses" should be tackled through strengthening the legislative branch. In fact, the legislative loopholes need to be resolved not only through supreme councils but also through multiple specialized and powerful commissions at Majlis. Nevertheless, the involvement of an assembly with powerful expert commissions requires a new design of the legislature branch, which cannot be covered in this paper.

Thus, Majlis will exercise real supervisory power on the executive branch through strengthening its mechanism in addition to organizing the government cultural and political structure in a way to enable Majlis for deeper inspections. For example, many of the administrative bodies in the government, exclusively receiving a portion of national budget, are exempted from any accountability and monitoring by Majlis. In fact, it is only the non-executive and headquarters status at the macro level of government (e.g., some departments or headquarter, consultancy and research positions) can remain immune to direct control from Majlis and either gain or lose Majlis vote of confidence, whereas the rest of bodies functioning as ministries should be held accountable.

Although the prominent instances of this issue are three supreme councils for Cultural Revolution, Cyberspace and National Security, certain decisions of them approved by the Supreme Leaders are no exception to the rule. Firstly, the activities of Supreme Council of the Cultural Revolution and Cyberspace have been developed according to the wisdom of Supreme Leader arising from fundamental loopholes and their essential involvement in correct guidance of the Islamic Revolution and the nation in two arenas of culture and cyberspace. Secondly, the issue of national security can be handled exceptionally in certain cases where it is undermined.

However, the progress of activities from supreme councils (in line with their scope of activities under the Constitution or Majlis law) should not be associated with the Supreme Leader, since the establishment of Supreme Councils of Cultural Revolution and Cyberspace, granting certain power to the National Security Supreme Council and designation of legal value to their decisions approved by the Supreme Leader have entirely been according to Article 110 of the Constitution 
in line with "determining the general policy of the Islamic Republic of Iran", "regulating the relationships between the three branches" and especially "solving the system's problems through alternative channels". However, the bills and laws enacted according to Islamic democracy and ideology of the Supreme Leader have been vested in the three branches, while the Leader is not supposed to expect other entities to carry out those tasks.

This was realized by the ninth government in 2007, but the multiplicity of supreme councils can be found in the system due to several reasons such as practical shutdown of supreme councils by the former government, legal deficiencies in a government bill, political clash between the former Majlis and ninth government, and ideological and practical conflicts between the ninth government and the previous one. Although the practical outcome of ninth government's approach to supreme councils led to their shutdown and engagement of the government bodies with numerous consequences for the country, the persistent trend in the legal status and number of supreme councils is now far from national best interests (Abuzar Zare Derakhshan, 2015).

\subsubsection{Legal status of supreme councils}

In line with implementation of Article 123 of Islamic Republic of Iran Constitution, law on outlining the status of supreme council approved in a public session dated April 13, 2008 titled Urgent Plan for Outlining the Status, Integration and Reform of Supreme Councils to the Islamic Consultative Assembly, which was communicated to the Nation's Exigency Council in accordance with Article 112 of IRI Constitution as follows:

From the date of enactment of this law, the following councils will be established and administered under these regulations while preserving their scope of powers, obligations and members as before:

1. Supreme Council of Science, Research and Technology, 2. Supreme Council of Education, 3. Space Supreme Council, 4. Supreme Council of Information Technology, 5. Supreme Council of Atomic Energy, 6. Supreme Council of Energy, 7. Economic Council, 8. Employment Supreme Council, 9. Supreme Council of Non-oil Exports Development, 10. Supreme Council of Welfare and Social Security, 11. Insurance Supreme Council, 12. Water Resources Supreme Council, 13. Currency Reserve Account Board of Trustees, 14. Council of Money and Credit, 15. Supreme Council of Cultural Heritage and Tourism, 16. Standards Supreme Council, 17. Environmental Protection Supreme Council, 18. Supreme Council of Informatics

Note - The government can submit any essential proposals to the Islamic Consultative Assembly to review the status of councils in terms of tasks, powers and number of members or merger into one another to enhance efficiency and continuous formation.

In fact, the number of supreme councils was modified by adoption of the above law, while other councils were either cancelled or merged.

\section{Conclusions}

Supreme councils dismantled on August 2007 became active in a new formation upon the approval of Nation's Expediency Council and Islamic Consultative Assembly in 2008. 
However, the spokesman for the ninth government announced the merger of 28 councils into 4 back in August 2007. This action was taken based on the decision of the Administrative Supreme Council in line with realization of the 20-Year Vision.

Based on this decision, the Supreme Council for economic planning and management was merged into Economic Council, while establishing the Employment Supreme Council, Supreme Council of Non-oil Exports Development, Supreme Council of Technical and Engineering Services Coordination, Supreme Council of Free and Industrial Zones, Board of Trustees for Foreign Exchange Reserves, Supreme Council of Welfare and Social Security, Money and Credit Council, Insurance Supreme Council, and Supreme Council of Consumption Patterns.

The Money and Credit Council, however, was revived again after Ahmadinejad's Administration, while the Economic Council formed again over the final months of tenth government.

The Supreme Council of Education, Research and Technology was formed by integration of Council of Science, Research and Technology, Information Technology, Communications, Space, Atomic Energy, Information Exchange Security, Education, Literacy Campaign Support, Informatics, Applied Sciences, Biotechnology and Standards.

Meanwhile, the tasks of Supreme Councils of Water, Energy and Environmental Protection were carried out by the Infrastructure, Industry and Environment Commission.

The tasks of the Supreme Councils of Cultural Heritage and Tourism, Iranians Abroad Administration Headquarters were merged to form a commission titled Cultural Heritage and Tourism and Iranian Abroad.

Now after 7 years since the approval of the Islamic Consultative Assembly, there are still a few of the 18 supreme councils not established yet. However, the current number of councils are faced with the question whether their decisions are as powerful as legislation. If so, then what are the obligations of Majlis as the only legislative body under the Iranian Constitution.

One of the most important issues concerning supreme councils is the legal status of their decisions and their position in the legislative hierarchy. Can supreme councils develop a legal act, the provisions of which should be enforced by competent authorities? How are the decisions of supreme councils related to Majlis? Can Majlis violate the approvals of supreme councils? Concerning the cultural issues, does the Supreme Council of the Cultural Revolution supersede Majlis and approve more effective decisions? To answer these questions, it is necessary to make sense of the law.

In defining the law, experts have noted: It refers to the general rule prescribed by the competent authority, approved by the legislative branch and then communicated to and enforced by the competent authority ${ }^{1}$. It has also been argued: Nowadays, any rule of any inherent nature arising from legislative bodies refers to law.

\footnotetext{
${ }^{1}$ In defending the absolute rule and revision of the constitution, Supreme Leader Ayatollah Khamenei stated: "We have expressed absolute rule in practice and even in statements, but the actions of the absolute rule and administration of the country by it should involve a system." Because the system needs to deal with its necessities and proves dysfunctional, where absolute rule supersedes to resolve the issue." Ibid, 1638.
} 
There is no doubt that the supreme council, orders are considered binding. From the perspective of the Constitution, "Actions of the legislative branch are taken through Majlis, which is composed of publicly elected representatives, whose decisions are communicated for enforcement to the executive and judiciary branches." .. In addition, the supreme council decisions are not applicable to the supervision of Guardians Council, i.e. this legal procedure is not practiced. Therefore, the supreme council decisions differ from law in terms of both the approval authority and during the legal procedures. Although these decisions are deemed binding legal rules, they are virtually not considered law. This statement is consistent with impression of supreme council and its decisions. At its eighty-eighth session (October 7, 1986), the Supreme Council of Cultural Revolution stipulated: "The government must be notified officially and in writing that the supreme council decisions are tantamount to the rule of law $^{2}$. If the supreme council decisions are in accordance with the law (rather than the law itself), then the legislative hierarchy is preceded by Majlis decisions.

This point should not be overlooked that if a vital decision of the supreme council is communicated to and approved by the Leader or the President, then the decision shall fall under the category of leadership and state commands. For that reason, it shall supersede the Majlis law, since Supreme Leader is the highest figure in the hierarchy, whose commands prevail Majlis decisions. The command of an Islamic ruler is considered Sharia ${ }^{3}$, which determines the validity or inconsistency of other decisions. In a position to comment on decisions of Majlis, the Guardian Council is supposed to investigate whether such decisions contrast the Constitution and Sharia rules, including the commands of the Supreme Leader.

It may be argued that The Supreme Council of Cultural Revolution has been formed at the behest of the Supreme Leader. Hence, all approvals of this entity are attributed to the leadership and considered provisions of Islamic rules. That is unacceptable. A command to establish an entity does not imply that all its decisions are validated. Similarly, Individuals and groups appointed by the Supreme Leader for a certain task, or entities operating under the leadership, carry out activities attributed and approved by the Leader. That statement has consequences that nobody is willing to recognize.

\footnotetext{
${ }^{2}$ Article 58 of the Constitution of the Islamic Republic of Iran.

${ }^{3}$ A lawyer of Guardian Council has recently argued: "The decisions of the Supreme Council of Cultural Revolution are not above the rules of Majlis." He also said: "If the leadership picks on a decision made by the Supreme Council of Cultural Revolution, the Guardian Council will declare that since the decision has been approved by the leaders and holds true as government rule, then none of the entities including Majlis shall violate the decision." Hayat-e No newspaper, May 21, 2002, p. 8 (speech delivered by Mohsen Esmaeili).
} 
Bulletin de la Société Royale des Sciences de Liège, Vol. 86, special edition, 2017, p. 332 - 340

\section{References}

1. General Department of Laws and Regulations, collection of decisions made at Supreme Council of Cultural Revolution, Institute for Information, first edition, 1993, Vol. I, pp. 1211.

2. Ansari, Valiollah, General Administrative Law, Mizan Publicationsm fall 2007.

3. Jafari Langroodi, terminology of law, Ganj-e Danesh, Seventh Edition, 1995, p. 517.

4. Sharif, Mohammad, legal status of Supreme Council of Cultural Revolution and the degree of its decisions,

Research of Public Law Issues. 15 and 16, fall and winter 2005.

5. Sarrami, S., Governmental rules and exigency, Rahbord Research Journal, Issue. 4, fall 1994.

6. Tabatabai Motameni, M., administrative law, SAMT, fourteenth edition, summer 2008.

7. Fallahzadeh, Ali Mohammad, Status of Court of Administrative Justice in the Constitution of the Islamic Republic of Iran, a law research, Strategic Research Center of the Expediency Council, first edition, 2007.

8. Ghazi Shariatpanahi, A., Principles of fundamental rights, Fourteenth Edition, Tehran, Mizan Publications, 2004.

9. Katuzian, N, philosophy of law, Volume II, Enteshar JSC, 1998.

10. Katuzian, Nasser, introduction to law, 33th edition, Enteshar JSC, 2003.

11. Kadkhodaie, AA, the need to protect the Constitution and the rights of citizens, Book Review, Vol. VII, Issue. 28, 2003.

12. Gorgi, AA, rule of law and the limitations of the right to petition at the Court of Administrative Justice, Fundamental Rights, Issue. 9, Summer 2008.

13. Malmiri, Ahmad, rule of law, concepts, principles and interpretations, Legal Studies Office of Majlis Research Center, Second Edition, Winter 2006.

14. Mahmoudi, J., reflection on theory of Guardian Council's interpretation of the powers of the Administrative Justice Court, Fundamental Rights, Issue. 5, 2005.

15. Morteza'i, SA, examining the supervision of the Guardian Council, Marefat, twentieth year, Issue. 165, August 2011.

16. Malekafzali, M, status and credibility of the Supreme Council of Cultural Revolution, Islamic state thirteenth year, Issue. 48, Summer 2008.

17. Musazadeh, Reza, administrative law (2-1) Overview and Iran, Tenth Edition, Tehran, Mizan Publications, 2008.

18. Hashemi, SM, fundamental rights of the Islamic Republic of Iran, two volumes, Tehran, Mizan Publications, 2014 and 2015editions.

19. Elham, GH and Maybodi, Mostafa, reviews on interference from Supreme Council of Cultural Revolution with decisions of Majlis, Government and the Expediency Council, Journal of Islamic Law, Issue. 37, fourteenth year, spring and summer 2013. 
Bulletin de la Société Royale des Sciences de Liège, Vol. 86, special edition, 2017, p. 332 - 340

20. Hedayatnia, Farajollahi, legal status and decisions of the Supreme Council of Cultural Revolution, Ravagh Anidesheh, Issue. 8, June and July 2003.

21. Varaee, SJ, foundations and documentation of the Constitution according to legislator, Secretariat of the Assembly of Experts Press, Qom, 2006. 